Meta

Journal des traducteurs

Translators' Journal

\title{
Training Translators in China
}

\section{Jianzhong Xu}

Volume 50, numéro 1, mars 2005

Enseignement de la traduction dans le monde

Teaching Translation Throughout the World

URI : https://id.erudit.org/iderudit/010671ar

DOI : https://doi.org/10.7202/010671ar

Aller au sommaire du numéro

Éditeur(s)

Les Presses de l'Université de Montréal

ISSN

0026-0452 (imprimé)

1492-1421 (numérique)

Découvrir la revue

\section{Citer cet article}

Xu, J. (2005). Training Translators in China. Meta, 50(1), 231-249.

https://doi.org/10.7202/010671ar

\section{Résumé de l'article}

Si l'enseignement de la traduction en Chine remonte loin dans le temps, il ne s'est considérablement développé qu'au cours des deux dernières décennies. Cet article passe en revue l'histoire de l'enseignement de la traduction en Chine et analyse la situation actuelle en examinant les programmes, les supports et les méthodes pédagogiques, l'enseignement de l'interprétation, la formation spécialisée en traduction et les tests d'habilitation. Il se termine par plusieurs propositions destinées à améliorer la formation des traducteurs en Chine.
Ce document est protégé par la loi sur le droit d'auteur. L'utilisation des services d’Érudit (y compris la reproduction) est assujettie à sa politique d'utilisation que vous pouvez consulter en ligne.

https://apropos.erudit.org/fr/usagers/politique-dutilisation/ 


\title{
Training Translators in China
}

\author{
JIANZHONG X U \\ Shaanxi University of Science and Technology, Shaanxi, China \\ xujianzhong2003@yahoo.com.cn
}

\begin{abstract}
RÉSUMÉ
Si l'enseignement de la traduction en Chine remonte loin dans le temps, il ne s'est considérablement développé qu'au cours des deux dernières décennies. Cet article passe en revue l'histoire de l'enseignement de la traduction en Chine et analyse la situation actuelle en examinant les programmes, les supports et les méthodes pédagogiques, l'enseignement de l'interprétation, la formation spécialisée en traduction et les tests d'habilitation. Il se termine par plusieurs propositions destinées à améliorer la formation des traducteurs en Chine.
\end{abstract}

\begin{abstract}
Translation training in China has a long history, but it is only in the last two decades that translation training has been developing increasingly fast. This article firstly reviews the history of translation training in China, then examines its present practice such as training program, training materials, training methods, interpretation training, advanced translation training, and Translator Accreditation Tests, and finally makes suggestions for improvement of training translators in China.

\section{MOTS-CLÉS/KEYWORDS}

translation training, China, interpretation, Translator Accreditation Tests
\end{abstract}

Recorded history demonstrates that translation training in China has been carried out for about four thousand years, but there are no details about it. It is only in the last twenty years that translation training in China has been developing very fast. With the development of information technology, China is in great need of translators, which in turn promotes the progress of translation training. Here we just examine the translation training in the mainland of China.

\section{A brief history}

Translation training in China has a very long history, and has its unique characteristics. So it is necessary for us, first of all, to review the history of translation training in China.

\section{Before the 20th century}

There have been translators since antiquity when people knew how to use language to communicate. Translation as a profession dates back a long time. However, the task of the translator has been, on the whole, to act as an intermediary, to facilitate understanding, and to remain silent and unnoticed. No records show any translation training in primitive society in China. The limited records indicate there were some translation activities in the Xia Dynasty (about 2000 BC-about 1500 BC) and the 
Shang Dynasty (about 1500 BC-1000 BC). However, the records are so simple that we cannot obtain the details of it. The earliest establishment of "translating official" in China goes as far back as the Zhou Dynasty (1100BC-770 BC). According to the written records, there were official posts called Ji, Xiang, Yi, Xiang Xu, Chong Yi and She Ren respectively in the eastern, western, southern and northern part of China. These translating officials had, at that time, a dual function: translating for internal and external purposes. The internal purpose referred to the translating between the central imperial government and various ethnic nationalities, while the external purpose was for communication between the central imperial government and its neighboring states. Oral interpretation came into being earlier than written translation which appeared in the Spring and Autumn period (770 BC-476 BC) in ancient China.

Recorded history in China tells us that translation training in China began with the translation of Buddhist sutra in the late the Han Dynasty (25-220), greatly developed in the Three Kingdoms (220-280), the Jin Dynasty (265-420) and the Northern and Southern Dynasties (420-581), was prosperous in the Tang Dynasty (618-907), was weak in the Song Dynasty (960-1279), and ended in the Yuan Dynasty (12711368). During this long period, Xuan Zang (602-662) was a key figure in both translation of Buddhist sutra and training of translators.

Xuan Zang was a great monk in the Tang Dynasty (618-907) who devoted all his life to the translation of Buddhist sutra from Sanskrit into Chinese and to the training of the translation staff. By studying the practice by translators before him and summarizing his own experience of translating Buddhist sutra, he eventually established his unique theory on translation that revolutionized translation theory and practice in ancient China. The core of his theory was faithfulness to the source language. Thus in practice, he emphasized much on transliteration and developed some specific ways to practice his theory. In his translation of Buddhist sutra he put forward the so-called "Five Non-translatable Categories":

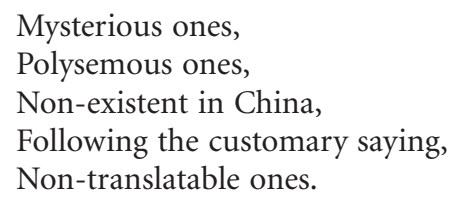

This is one of his suggested ways to ensure transliteration. Xuan Zang was the head of the center of translation Buddhist sutra. He did not only a great deal of translation but also the translation training in Chang'an (now Xi'an), the capital city of the Tang Dynasty. Unfortunately we know little about his training program. The translation of Buddhist sutra is the first of the three climaxes in the translation history in China, which lasted for over one thousand years. Such a great project needed many translators with no doubt some 150 translators working on the project at any one time. Apart from Xuan Zang, there must be other translators who did translation training, but there is very little information on this. The interesting thing is that the early translation of Buddhist sutra was done as a cooperative venture between a foreigner and a Chinese, with the former working as an interpreter, and the latter as a notetaker and polisher.

It has been common practice to employ foreigners working in China as translators in many periods in history. For example, Ferdinand Verbiest (1623-1689, Belgian), Nicolas Joseph Raux (1754-1801, French), Samuel Halliday Macartney (1833-1906, 
English) were once employed as diplomatic translators; Robert Morrison (17821834, English), Charles Gutzlaff (1803-1851, German) as trade translators; Thomas Pereira (1645-1708, Portuguese as a military translator; Mathiou Ricci (1552-1610, Italian), Jean Ferrenz (1574-1659, Swiss) as scientific translators. The reason for employing foreigners as translators in China is that the Chinese usually thought their country was the most powerful in the world (even though they were backward in certain periods), so there was no need for them to learn foreign languages.

However, some foreigners, for their own interests, did something harmful to China and Chinese in their translating. As a result nearly all of China's rulers acted to establish translator training schools and to train their own translators. The very early history of China saw the training of translators, but not formal language schools. The first formal translator school in China was Hui Hui Guo Zi Xue (Huihui Translation School), established in1289. The other famous language schools in history are Si Yi Guan (Foreign Languages School) established in 1407, Si Yi Guan (Translation School) established in 1644, and Tong Wen Guan (Tongwen Foreign Language School) established in 1862. These schools employed not only Chinese but also foreigners as instructors, such as W. A. P. Martin (English, in 1864), A. E. Smorrenberg (French, in 1862) and N. A. Konvaloff (Russian, in 1898). Among the four schools, we only find the teaching and learning system in Tongwen Foreign Languages School. At the beginning, the school only offered English, then French, German, Russian and Japanese. The students spent eight years doing translation practice from informal note and official document translation to book translation. These were the first translators and teaching staff officially trained in China. Graduates from the school did translating work in various fields, but they could not meet the needs for quality and volume at that time.

\section{2-1949}

Tongwen Foreign Language School merged with the Translation Department, Jing Shi Da Xue Tang (The National University) in 1902. It offered English, Russian, French, German and Japanese. It marked the beginning of foreign language specialty in Chinese higher institutions. Students were required to study not only foreign languages but also Chinese. The teaching goal was that they could not only read and translate foreign books, but also do the interpretation and the compiling work. Translation was one of the teaching goals, but it has long been used as a teaching method.

After the Republic of China was founded in 1912, foreign language learning was stressed. As a result, there emerged foreign language schools and departments in two-third of the universities. However, foreign language students only learned linguistics, and English and American literatures. No translation course was offered.

In order to train military translators needed in the Anti-Japanese War (19371945) as well as diplomatic staff for the People's Republic of China (founded in 1949), the Central Committee of the Communist Party of China and its Military Commission established a school, Yan'an Foreign Language School, in 1941. It offered Russian and English. Translation, including oral and written, was a major subject at the school. Translation training did not begin until the students had learned the basic grammar and 2000-3000 words. There was no textbook, no theory or skills, so 
translation was learned through practice. Yan'an Foreign Language School, in this way, trained great number of translators and diplomatic staff, which paved the way for later translation teaching and training.

On the whole, from 1920 to 1949 nearly all universities used Grammar-Translation technique as a means of learning foreign languages. There were less formal translation trainings.

\section{9-1976}

The People's Republic of China (PRC) was born in 1949, and the government established several foreign language institutes. One of the tasks of foreign language schools was to train translators and teaching staff. For instance, the Russian specialty divided the students into two parts: seventy percent of them for translators, and the rest for teaching staff. “The Seven-year Plan for Foreign Language Teaching” issued by the Ministry of Education claimed that the primary goal of some foreign language institute could be for translating purposes. i.e., for training translators, even advanced translators. With this policy, translation training gained increasing importance.

However, the formal translating teaching and training were not carried out at all. In the early 1950s, foreign language schools paid considerable attention to listening, speaking, reading and writing skills, and they ignored translating. According to the Ministry of Education's plan, translation was an independent and required course. But colleges and universities carried out the plan differently, with some offering the course, and others not. Translation was a new course and it was hard for them to have a complete teaching and learning system. Although the country greatly needed many professional translators, the graduates from colleges and universities could not meet the urgent need.

The political movement, the so-called "Great Cultural Revolution" (from 1966 to 1976), inflicted great damage on the teaching and learning system. And translation could not escape this calamity.

1977-

The end of "The Great Cultural Revolution" meant a new era in the development of translation training in China. In light of the plan issued by the Ministry of Education in 1979, translation became a required course, thus establishing the role of the translation course in foreign language majors. Then came a series of translation textbooks that were the first series ever published in China, thus greatly promoting translation training in China. Translation training in China entered a formal phase. The Chinese Translators Association (CTA) was established in 1982, and has made a great contribution to translation training. CTA's learned publication, Chinese Translators Journal (bimonthly, in Beijing), as well as Chinese Science \& Technology Translators Journal (quarterly, in Beijing), Shanghai Journal of Translators for Science and Technology (quarterly, in Shanghai) and English of Science and Technology Learning (monthly, in Shanghai) have been offering training classes or summer schools to provide various kinds of translation training. Beijing Foreign Studies University, trusted by the Chinese government and the United Nations (UN), established in 1979 the UN Translator Training Center (now Advanced Translation School), training translators and simul- 
taneous interpreters for the UN. So far it has trained 217 translation personnel who worked and are working in the UN organizations in New York, Geneva, etc. Their performance is greatly appreciated by the UN. It now trains advanced translation personnel not only for the UN but also for domestic use. The first Translation Department in China was founded at Guangdong University of Foreign Studies in 1997. The Translation Department was founded at the Hunan Normal University and Zhongshan University in 2002. The advanced translation school was established at Shanghai International Studies University in 2003, comprising an interpretation department, translation department and translation studies center. Having obtained permission from the authorities, the school now becomes the first in China's mainland with the right to award master's and doctor's degrees of translatology. Many translation studies centers have also been founded in numerous universities such as Nankai University, Eastern China Normal University, Central China Normal University, Guangdong University of Foreign Studies, Shanghai University, Shanghai International Studies University, and Eastern China University.

\section{Translation training}

The recorded history of China indicates that translation in China began a long time ago, but yields no details about it except Tongwen Foreign Languages School (1862). Records say that the school stressed not only a good command of source language (SL) and target language (TL), but also a knowledge of many other branches of learning, including the following:
Astronomy,
Mathematics,
Physics,
Chemistry,
Biology,
Botany,
International law,
National policy.

Students would spend eight years studying the above in order to complete the school. It had the following examinations:

Monthly (first day of each month),

Quarterly (first days of February, May, August and November),

Yearly (in October),

Every Three Years (the key examination).

The school trained both written and oral translators from a foreign language to Chinese and vice versa, stressing practice writing. (MA, Z. Y. 1999:66)

Translation training in contemporary China is divided into two parts: training at school and training at work.

\section{Training at school}

For several decades there has been a false idea that graduates from foreign language schools or departments could do the translation automatically, therefore translation is only a course in the undergraduate's curriculum, that is to say, no school or foreign 
language department offers formal translation training. Although the curriculum issued by the Ministry of Education set translation as a required course in 1950, some schools didn't offer the course for various reasons such as lack of competent teaching staff and textbooks. Since 1978 translation has been a required course for the senior students in the light of the teaching plan and outline for the foreign language majors issued by the Ministry of Education. All the foreign language departments and schools have been offering the course. Taking English major as an example, translation consists of English-Chinese translation and vice versa. Both written translation and oral interpretation courses are offered to the seniors two periods each week.

Translation is a new course in China, and there is no complete system. Therefore, different instructors apply different teaching plans, books and tests according to their own understanding of translation. In the light of the teaching program for the English-major seniors, the translation course offers not only theory but also practice, not only comparisons of Chinese and English, but also general translation skills. It is generally accepted that, in order to solve the problems students meet in their translation practice, the instructor should selectively offer some theory on the basis of practice. It includes the following:

Brief history,

Translation criteria,

Schools of translation studies,

Translation skills.

For undergraduates, theory teaching takes up 30 percent, and practice 70 percent; and for postgraduates, theory teaching 50 percent, and practice 50 percent.

It is generally accepted that postgraduates aimed at translation theory and practice should study the following required courses:

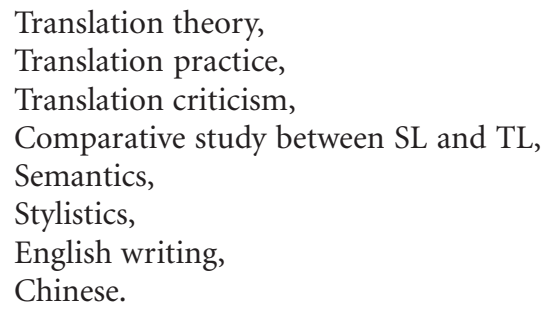

But different schools or departments offer different courses according to their training plans. The required courses offered to the postgraduates aimed at translation and practice (written translation) in the English Department, Beijing Foreign Studies University are as follows:

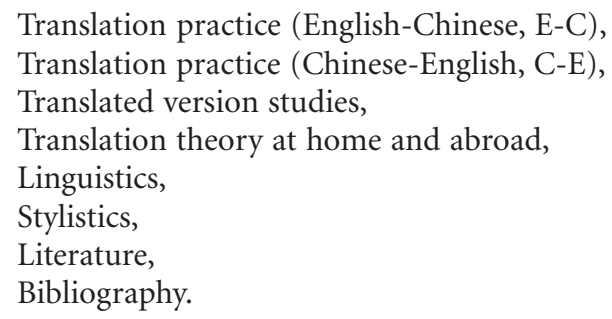

And the courses offered to those aimed at translation theory and practice (simultaneous interpretation) are as follows: 
Consecutive interpreting (E-C),

Consecutive interpreting (C-E),

Simultaneous interpreting $(\mathrm{E}-\mathrm{C})$,

Simultaneous interpreting (C-E),

Sight interpreting (E-C),

Sight interpreting (C-E),

Written Translating (E-C),

Written Translating (C-E),

Translation theory.

Usually the students take the mid-term and final examinations every term.

\section{Training at work}

Training at work is another way of training translators. Since the graduates from foreign language schools or departments only learn some basic translation theories and skills that stress literary translation and know little about the related knowledge of their work, and the graduates from other specialties know the scientific knowledge but are poor in a foreign language, especially the listening, speaking and translating abilities, it is necessary for them to do the further training. This kind of training comprises self-training and enterprise training.

Usually enterprises have training programs or training centers to train their professionals. Enterprises encourage their employees to do self-training or to do the training in the work sites so as to adapt to their new work quickly. Those who have scientific knowledge but are poor in foreign language are usually sent to the foreign language schools or departments for further study, or to the training class or summer school held by certain organizations such as Beijing Foreign Studies University, Shanghai International Studies University, Shanghai University, Guangdong University of Foreign Studies, Xiamen (Amoy) University, China Translation \& Publishing Corporation, Translators Association of China, Shanghai Translators Association for Science and Technology, the editorial departments of Chinese Translators Journal, of Shanghai Journal of Translators for Science and Technology, and of English of Science and Technology Learning. Those who possess a good command of a foreign language but are weak in scientific knowledge are sent to universities for further study. The trained professionals are very good translators.

The society needs this kind of compound personnel. Of course, translation training, like some other things, is a lifelong process. In the age of globalization, the earth becomes increasingly small, and the information and knowledge explosion is inevitable. Only by doing lifelong learning can we keep up with the progress. And the enterprises also know the fact that keeping their staff training is a never-ending process. They formulate the corresponding training regulations to build up learning organizations, and adopt various training methods for different staff so as to improve the diathesis of translators as well as their own competitive ability.

\section{Translating materials}

The quality of translation training, to some extent, depends on the training materials, i.e., translation textbooks. Since The People's Republic of China was born in 1949, over one hundred textbooks have been published (Zhang, M. F. 1999:53). They cover 
a lot of ground, including the basic course, interpreting, literary translation, technical translation, commercial translation, etc. We can divide the books into three parts: the school of morphology and syntax, the school of functional approach, and the school of contemporary translation theories. The following are some typical ones.

\section{School of morphology and syntax}

Lu, D. Y. (1958). English-Chinese Translation Theory and Practice. Beijing: Times Publishing House.

Zhang, P. J. et al. (1980). A Coursebook of English-Chinese Translation. Shanghai: Shanghai Foreign Language Education Press.

Feng, S. J. (1995). Practical English-Chinese Translation Skills. Shanghai: Tongji University Press.

\section{School of functional approach}

Wang, F. X. (1992). Chinese-English Interpretation Course. Beijing: Peking University Press.

Wu, B. et al. (1995). A Course in Oral Interpretation (revised edition).Beijing: Foreign Language Teaching and Research Press.

Guo, Y. D. \& Zhang, Y. (1995). Commercial English-Chinese Translation Course. Guangzhou: Zhongshan University Press.

Zhang, L. L. (1996). Practical English-Chinese Translation Skills. Guangzhou: Guangdong Education Publishing House.

Tan, B. Q. (1997). Modern English Translation Skills. Shanghai: Shanghai Jiaotong University Press.

Lin, Y. R. et al. (1999) Interpreting For Tomorrow: A Coursebook of Interpreting Skills Between Chinese and English. Shanghai: Shanghai Foreign Language Education Press.

Huang, Z. L. (2000). Study on Translation Variation. Beijing: China Translation \& Publishing Corporation.

Xu, J. Z. (2002). An Introduction To Enterprise Translation. Beijing: China Translation \& Publishing Corporation.

\section{School of contemporary theories}

Ke, P. (1993). English-Chinese \& Chinese-English Translation Course. Beijing: Beijing University Press.

Yang, L. L. (1993). A Course in English-Chinese \& Chinese-English Translation. Kaifeng: Henan University Press.

Fan, Z. Y. (1994). An Applied Theory of Translation. Beijing: Foreign Language Teaching and Research Press.

It is obvious that, except for the basic translation books, there are two kinds that are appealing: technical translation published from the late 1970s to the late 1980s, and interpreting and commercial translation published in the 1990s and in this century. These books reflect the needs of different personnel in the different periods.

From the works mentioned above, we can easily see that the mainstream of translation training in China is complete translation. But another important aspect of translation, translation variation, is ignored. The translation varieties comprise selective translation, edited translation, translated narration, condensed translation, translated summarization, translated commentary, translated writing, etc. (Xu, J. Z. 2000). 


\section{Training methods}

Translation is a new course in China, and there is no complete system. Therefore, different instructors apply different teaching plans, books and tests according to their own understanding of translation. In the light of the teaching program for the English-major seniors, the translation course offers not only theory but also practice, not only comparisons of Chinese and English, but also general translation skills. But how to teach remains unsolved.

Some instructors think it unnecessary for undergraduates to learn some theory. To them, practice is the main thing. They put stress on doing exercises and commenting on students' work. Others attach importance to both theory and practice. Specifically, some instructors let students do the homework first, then they explain some theories and skills related to students' translated version; some explain skills first, then assign homework, and finally critically comment on students' work; others give students the chance to discuss what they will do (leading students to the problems appearing in the translation process) after the homework is assigned, and then do the summarization.

The Advanced Translation School, Beijing Foreign Languages University has a creative way of training translators aimed at improving their efficiency and quality of the translation. According to the features and requirements of the professional translators training, they try to narrow down the distance between class teaching and practical experience, thus making the students learn the necessary translation theories and skills and reaching the professional standard through a great many exercises in both the real and visualized real surroundings. The ways are as follows:

1. As the students are trained to be translators working at international conferences, they offer some exercises in the visualized international conference. In this way the students not only get to know the procedure and norm of the conference but also are offered a chance to do a series of practice through direct participation in the whole process of the conference such as the conference preparations, the conference hosting, question-asking, and translation. In order to make the conference more genuine, they invite the scholars and experts from their university or other universities, at home or abroad, to participate in it. Through this kind of practice, students not only gain confidence and experience but also find their own weaknesses.

2. When the school undertakes some translation task, they put it into their teaching practice in order to polish the students in the actual operation. They take an assembly line approach to the translation work: with some translating, some typing, and still others doing the proofreading and correcting. The instructor's duty is to examine the translated version and offer comments and revisions to those who do the translation. This practice trains both their professional ability and their spirit of cooperation and commitment to the work.

3. Senior students, led by the instructor, are encouraged to undertake the translation work at international conferences and international cooperation projects, thus gaining the opportunity to do actual practice. In this way students can experience the atmosphere and pressure of the work that is quite different from exercices in the classroom. (Wang, L. D. 2002)

This way of training tries to do a perfect merge of class work and actual work, improving the traditional training methods and the efficiency and quality of the translator training. 


\section{Interpretation training}

Due to its unique features, the recorded history yields little detail about interpreting training, but it has been developing quickly in China in recent years. It is recorded that the first translation test held in Tongwen Foreign Language School in October, 1865 contained some interpretation, but no details about it. The translation course in Yan'an Foreign Language School comprised written translation and oral interpretation, but the latter was not taught as a special skill, but as a tool to improve students' expressive ability. Translation has been set as an independent course since 1949 , but stressing written translation and ignoring the oral interpretation. As a result, only a few out of four hundred higher institutions offer interpretation courses. At present, interpretation is a major only in five schools: Beijing Foreign Studies University, Guangdong University of Foreign Studies, Xiamen University, Shanghai International Studies University, and University of Business and Economics.

\section{Beijing Foreign Studies University}

Beijing Foreign Studies University (previous Beijing Foreign Language Institute), trusted by the United Nations (UN) headquarters and the Chinese government, established the UN Translator Training Center in order to satisfy the great need of the $\mathrm{UN}$ for C-E and E-C translation personnel. The training cycle is two years. Its graduates went to work in UN departments in turn. It enrolled 25 students every year, of whom ten were trained for interpretation. Later it enrolled decreasingly fewer. The training was given twelve times, and trained 217 personnel. The training work for the UN ended in 1993 since the UN translation staff work lifelong. From then on it began to train the students for domestic use. It became the Advanced Translation School in 1994, but the original name remains.

The goal of the school is to train students to do simultaneous interpretation and document translation at international conferences, or to do advanced translation work for the Chinese government. The teaching methods are as follows:

Do the basic training in interpretation and translation in the first year.

Divide students into two groups in the second year: one trained for simultaneous interpreting, the other for written translation and consecutive interpreting.

\section{Guangdong University of Foreign Studies}

The Advanced Translator Training Class, a cooperative project of Guangdong University of Foreign Studies and the British Counsel in the 1990s trained 13 postgraduates, 8 postgraduates (without degrees), and 78 undergraduates. On the basis of the class, the Translation Department was established in 1997, which offers translationmajor courses, enrolling postgraduates and the undergraduates from the juniors.

The goal of the department is to foster the competent translation personnel in trade, foreign affairs, diplomacy, international cultures and sci-tech exchanges. It offers nine key courses:

Communicative English,

Advanced English,

English writing, 
Consecutive interpreting,

Simultaneous interpreting,

Diplomatic interpreting,

Translation theory and practice,

Commercial translation,

Practical writing,

Diplomatic documents.

They not only train students in class but also take them to do practice in various places such as enterprises, trade fairs, foreign affairs offices, among which the bi-annual Guangdong Export Commodities Fair is the ideal place for students to practice.

\section{Xiamen University}

Xiamen University began to offer an interpretation course for its seniors in the mid 1980s. In the early 1980s the university cooperated with Deakin University (Australia) to carry out a program of study on interpretation teaching, including its content, training methods, testing and curriculum. From 1994 to 1998, as a cooperation program of State Education Commission (now Ministry of Education) and the British Counsel, Xiamen University and University of Westminster (UK) cooperated to do the interpretation teaching and studies (Li Y. R. 1999). As a result of the program, the group published a course Interpreting For Tomorrow in 1999. The Translator Accreditation Test Center was established in the school in June, 2002. Since its establishment the center has successfully held several interpreter training classes and Translator Accreditation tests. From 2002 to 2003 they participated in the "Sino-EU Support China Entering WHO Program" subsidized by European Union (EU), and undertook its interpreting training three times. What's more, the center, on behalf of China, participates in the "EU Subsidized Asia-Europe Interpreter Training Program" that began in January, 2004, and will end in June 2005. The purpose of the program is, through fostering outstanding interpretation personnel, to promote the political, economical and cultural exchanges between Asia and Europe, and to publish multimedia interpreting training textbooks.

\section{Shanghai International Studies University}

The Advanced translation school was established at Shanghai International Studies University in April, 2003, and the interpretation department is one of its three institutions. It offers courses to postgraduates and doctoral candidates.

\section{Training curriculum}

It is generally accepted that interpreting teaching comprises two parts: the skill training, and the training of background knowledge concerning interpreting. The former includes:

Memory training,

Number training,

Note-taking,

Repetition, 
Public speaking,

Logical thinking and coherence,

Coping tactics,

Professional behavior,

Sight interpreting,

Interpreting preparation,

Consecutive interpreting,

Simultaneous interpreting.

The latter consists of:

Foreign affairs,

Foreign policy,

Political system,

About Hong Kong, Aomen (Macao) and Taiwan,

Human rights,

Economy,

Trade,

Environment protection,

Tourism,

Education,

Literature and art,

Population,

Medical care,

Sports,

Military,

Religion,

Minority nationalities.

\section{Evaluation}

As for the evaluation of the students' performance, accuracy and fluency are the first concern. At Xiamen University, information transformation or competence takes up $30 \%$, accuracy $30 \%$, expression $10 \%$, fluency or speed $10 \%$, articulation $10 \%$, and emergency measure $10 \%$. And at the University of International Business and Economics, accuracy takes up 60\%, fluency $30 \%$, overall impression (pronunciation, intonation, bearings) $10 \%$.

\section{Advanced translation training}

Advanced training in China is done in some universities and institutions, but the training in the Foreign Affairs College and Ministry of Foreign Affairs is typical.

\section{Foreign Affairs College}

The Foreign Affairs College has been offering translation training for about thirty years, fostering advanced translation personnel. The training program began in 1985 on the basis of the established postgraduate program. In order to do a good job, they do the following things:

1. Enroll outstanding students who can adapt to the intensified advanced translator training,

2. Compile a series of course books, including comprehensive translation skills and the related foreign affairs training, 
3. Choose excellent teaching staff members,

4. Have good cooperation with the Ministry of Foreign Affairs and other institutions, offering students the related lectures.

In the design of their training program they, in the light of the conditions of their teaching staff, increase the hours of practicing skills and intensify E-C and C-E written translation. They offer the following courses:

Cultural translation,

Diplomatic and foreign affairs translation,

Economic translation,

Sight translation,

Simultaneous interpreting.

They offer a total of 288 hours of classes. Students are required to listen to foreign radios and television stations for two hours every day, so in a two-year training they will practice 1400 hours. Only a few students become simultaneous interpreters upon completion; others will receive further intensified training for over 500 hours.

They train both advanced interpreters and translators. Four instructors with rich translation experience lecture on both E-C and C-E translation for the two academic years. They stress translation approaches. Their training materials contain:

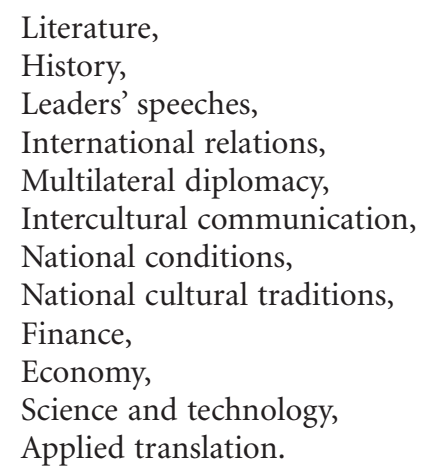

In the age of information explosion, cooperation in translation seems very important due to the urgency and amount of materials to be translated. Cooperative training is done in the following stages:

1. The organizer must read over the original, mastering its content, style and language features,

2. Determine not only the translated terms of the frequently used words, new words and the proper names but also the unified expressions of the abbreviated forms,

3. Choose the proper personnel to do the translation,

4. Divided the original into several parts and assign the task according to each member's specialty,

5. The organizer must must know how to use library and on-line resources, direct the members in applying them,

6. All the members should discuss the translations of certain phrases or expressions they encountered in their work,

7. The organizer verify and revise the composed translated version, pay great attention to if they use unified words, if the style is the same as the original, and if the sensitive expressions can lead to misunderstanding, 
8. Distribute the verified versions to their translators and ask for their comments,

9. If permitted, ask experts to verify and revise the version.

Team work can foster students' team spirit, harmonious thinking, and unified style, which are vital in their future career.

\section{Ministry of Foreign Affairs}

The Translation section, Ministry of Foreign Affairs, consists of brilliant translation personnel in China, and it is generally accepted that it represents the top of translation in China. In order to maintain the high level of its personnel and to foster the newcomers, it has established a set of advanced translator training projects based on its years of training experience. The following is what they do:

1. Select the best through strict examinations

Apart from the high ideological quality, the candidates must undergo a series of tests:

Government public service test,

English and Chinese proficiency tests,

Interview in English.

Through the tests, select 10-15 candidates who will take the "observing training," i.e., elimination training, which means the intensified training for three weeks. The purpose of it is to test the candidates'

foreign language ability,

potentiality of translation competence,

comprehension capacity,

expressive habits,

voice condition,

hardworking spirit,

mental and physical diathesis for work under pressure,

organizational ability,

perfect discipline.

Only seven or ten candidates are enrolled to receive formal training after the "observing training."

\section{Intensified training program, involving a great deal of practice}

The purpose of the program is, through the half-year's centralized, intensified and pressure training, to improve the students' overall ability, especially on-the-spot interpreting competence, to familiarize them with the requirements of diplomatic translation and translation skills, and to constantly improve their translation competence in the light of the work requirements. All the courses are lectured by senior translators and retired translation experts who, through their experience, can demonstrate their superb style and translation techniques that are a great inspitation to students. The training is intensive. Every day the students must first listen to VOA and $\mathrm{BBC}$ for half an hour. Then they must do the memory, note-taking, oral interpretation and written translation trainings. The materials include the daily news, commentary and current issues, so that they form the habit of following ongoing events. The training features practical examples and lectures on translation theory, rhetoric, and diplomatic translation. 
To spur a competitive spirit, the program organizes various activities such as speed contests, debates, seminars, and weekly news summaries. During the training process, students undertake many translation tasks, and have ample opportunity to view and emulate on-the-spot translation encountered at news and press conferences.

\section{Stressing accuracy}

Listening ability is stressed during the training as the basic requirement for translators on diplomatic occasions. Students are trained to master British and American pronunciations, as well as those of other Englishes, to be familiar with different tone qualities and speaking habits, and even with ungrammatical English. In order to achieve accuracy, students are also trained to keep track of events and situations at home and abroad, to obtain enough background knowledge, and to pay careful attention to "word," "story" and "message."

4. Emphasizing the relevant qualities

A sharp memory and note-taking skills are necessary for diplomatic translators. The program offers two kinds of trainings: pure memory and note-assisted memory in order to improve their ability to recall more in less time. Through the trainings students master the logical mnemonics, allowing them to live their parts instantly, to grasp the key idea of the sentence and the logical relation among sentences accurately, and to sort out the accepted information promptly. Their expressions must be clear, neat and concise. Students must be familiar with diplomatic specifications, practice relevant topics, build their own vocabulary and exchange it with their fellows regularly. They are trained to attach importance to both quality and quantity, and to know how important consulting is, where to consult, how to consult, and how to use various resources.

\section{Translator accreditation tests}

Translation accreditation tests issued by the Ministry of Personnel are divided into the third grade, second grade, first grade, and top grade. Grade 3 is designed for nonforeign-language-major graduates who have passed College English Test band-six (CET-6) and had some translation experience, or for two-year foreign-languageschool graduates. Grade 2 is designed for non-foreign-language-major postgraduates or graduates from a four-year foreign language department or school, who have had three-year or five-year translation experience. Grade 1 is for those who are good at E$\mathrm{C}$ or $\mathrm{C}-\mathrm{E}$ translation and have had years of translation experience. The top grade is for the brilliant translators, who are equal to full professors. The test is open to all. It contains a comprehensive test and professional test, including oral interpretation and written translation, and the oral interpretation comprises simultaneous interpreting and consecutive interpreting.

The test is professional and stresses competence. Considering a person is unlikely to be good in every field, the test is divided into two parts: one is the required item, the other alternative one, i.e., the candidates can choose one item from the two or three. It reflects fairness and objectiveness.

The test (grade 3 and grade 2) was first held in Beijing, Shanghai and Guangzhou on November 6 and 7, 2003. It will be held in more provincial cities this 
year, and will be nation-wide in 2005. At present, only the English test is offered but other language tests will appear in the near future.

National translator credentials offer fair and objective measurement, and play a very important role in the standardization of translation conduct, the guarantee of translation quality, and the protection of the translator's rights. It is a guide to translation training of various levels and types, and sets a high demand for the training.

\section{Problems and perspectives}

At present, there are some problems about translation training in China, which hinder the progress of the professionalism of translation education. It is generally accepted that there are at least five problems: lack of translation departments or schools and teaching staff; translation teaching or training seen as a method of or supplement to foreign language teaching; emphasis on complete translation; doing more translation studies than translation training; informal training in some short-term training class.

At present there are too few translation departments, schools, and translation centers, which does not meet China's enormous need for competent translators in the era of information technology. More translation departments, schools, and translation centers must be established and more teaching staff trained in order to meet the challenge. And the two courses, technical writing and integrated science, should be offered for training translators.

The State General Administration of Quality Supervision, Inspection and Quarantine of PRC issued on November 27, 2003 Specification for Translation Service Part 1: Translation (implemented on June 1, 2004) aims at standardizing translation services and improving service quality. Translation is officially recognized as a profession, and translation is rather a skill than a method of foreign language teaching, which is very important to translation training because the teaching method cannot reach the requirements of training translators.

The training should attach equal importance to both complete translation and translation variation so that it can meet the special needs of the different clients.

Nearly all the postgraduate programs in China focus on translation studies and ignore translation skills, but skills cannot be replaced by theory due to the features of translation training. Translation theory is important, but translation skill is more important in translation training.

While the Translator Accreditation Test offers an objective measurement for testing the effect of a translation training course, it sets new requirements for translation training. So translation training should stress the entrance examination, specific item training, comprehensive training, training result analyses, knowledge and skill training, and psychological training.

The entrance examination is the first link of the chain, and it offers information about the candidates. Divide them into different groups according to their levels. "Suit the remedy to the case," as an old Chinese saying says. Adopt different approaches and materials for different groups. It is necessary for translation departments, schools or training centers to select the outstanding students from the juniors to take translation training.

Translation is a complex mental activity, and it requires students to be good not only at listening, speaking, reading, writing and translation, but also at applying 
translation skills. But mastering skills requires a period of time, so specific item training in translation strategies and skills are needed to achieve an excellent training result.

Translation is complex work involving different skills, and demands good coordination of them. Therefore, while specific item training is necessary, comprehensive training is also a must because such complex ability is not the simple blending of the specific skills, but the coordination and distribution of mental power to all the skills.

Students cannot analyze the problems they encounter during the translation process, so it is necessary to analyze the result and solve the confronted problems after specific item training, which is also an effective way of learning.

Translation work concerns various walks of life, and it is necessary for translators to possess both language skills and professional knowledge. Students should not only master translation skills but also deliberately widen their knowledge scope such as the basic knowledge of various specialties and the remedies for lack of specific knowledge on certain occasions.

Mental training is very important for competent translators because they usually work on public occasions. So apart from translation skill training, it is important to train students to speak skillfully in public and be mentally strong to bear high pressure.

Translation is a practical activity. Effective and systematic training can greatly improve students' translation skills and working efficiency in a short period of time. However, translation skills must be put into practice regularly in order to reach a higher level. The Translator Accreditation Test is the measurement and attestation of translation workers' professional ability, and it represents the new starting point in their careers.

\section{REFERENCES}

BAo. C. Y. (2003): "Key Considerations in Translator and Interpreter Education," Chinese Translators Journal 2, pp. 48-50.

CaI, J. G. (2003): "On the Necessity and Feasibility of Taking the Translation Course on the Part of College Students," Chinese Translators Journal 1, pp. 63-66.

CAI, X. H. (2001): "Interpretation Study with an Interdisciplinary Perspective," Chinese Translators Journal 2, pp. 26-29.

Chen, J. (2002): "Fundamental Considerations in Interpreting Teaching," Chinese Translators Journal 1, pp. 51-53.

Chen, J. (2003): “On Communicative Approach to Interpreting Testing," Chinese Translators Journal 1, pp. 67-71.

Chen, K. Q. (2002): “Thoughts About College English School Translation and Translation Teaching," Foreign Languages and Their Teaching 7, pp. 42-44.

Chen, Z. D. \& Zhang, S. S. (2003): “On Interpretation and Interpreting Teaching," Shanghai Journal of Translators for Science and Technology 1, pp. 29-32.

Du, Y. H. (2002): "Improve Diathesis of Translators in the Trend of the Time," Chinese Science \& Technology Translators Journal 4, pp. 36-38.

FAn, S. Y. (2000): "Advanced Translator Training in Foreign Affairs College," Chinese Translators Journal 1, pp. 64-65.

Fan, Z. Y. (1994): An Applied Theory of Translation, Beijing: Foreign Language Teaching and Research Press.

FANG, J. Z. (2002): “Principles of Writing a Course Book for Interpreting Studies," Chinese Science \& Technology Translators Journal 2, pp. 22-24.

Feng, S. J. (1995): Practical English-Chinese Translation Skills, Shanghai, Tongji University Press. 
Feng, Y. H. (2001): “Collaborative Translating Instruction on Classroom Net," Chinese Translators Journal 2, pp. 37-40.

Guo, Y. D. \& Zhang, Y. (1995): Commercial English-Chinese Translation Course, Guangzhou: Zhongshan University Press.

HaN, Z. Y. (2002): "Function of Note-taking on Interpretation," Chinese Science \& Technology Translators Journal 2, pp. 25-26,33.

Hu, Q. P. (2004): "Technical Writing, Integrated Science and Sci-Tech Translation," Chinese Science \& Technology Translators Journal 1, pp. 44-46.

Huang, Z. L. (2000): Study on Translation Variation, Beijing: China Translation \& Publishing Corporation.

Huang, Z. Y. \& Li, Y. S. (2003): “On System of Translation Strategies,” Shanghai Journal of Translators for Science and Technology 4, pp. 10-13, 25.

Ke, P. (1993): English-Chinese \& Chinese-English Translation Course, Beijing: Beijing University Press.

Ke, P. \& Bao. C. Y. (2002): "Programs Currently Offered and Research Projects Currently Conducted in Major Tertiary Institutions in the World," Chinese Translators Journal 4, pp. 59-66, 5, pp. 52-59, 6, pp. 45-51.

LI, N. Q. (2002): China Interpretation History, Qingdao: Qingdao Publishing House,

LI, Y. X. (2003): “On Teaching Translation in a Textual Perspective," Chinese Translators Journal 4, pp. $58-62$.

Lin, B. C. (2000): "On the Importance of Non-Literary Translation and the Training of NonLiterary Translators," Shanghai Journal of Translators for Science and Technology 2, pp. 34-37.

Lin, Y. R. et al. (1999): Interpreting For Tomorrow: A Coursebook of Interpreting Skills Between Chinese and English, Shanghai: Shanghai Foreign Language Education Press.

Liu, B. \& Du, Y. W. (2003): "A Study of College Students C-E Translation Ability," Chinese Science \& Technology Translators Journal 3, pp. 31-33.

Liu, J. C. (2003): "On the Need to Promote Research on Textbooks of Translation Out of Chinese," Shanghai Journal of Translators for Science and Technology 3, pp. 52-55.

Liu, H. P. (2001): Interpretation Skills, Beijing: China Translation \& Publishing Corporation.

Liv, H. P. (2003): "New Features of Interpretation and Teaching of Interpreting," Chinese Translators Journal 3, pp. 32-36.

Lu, D. Y. (1958). English-Chinese Translation Theory and Practice, Beijing: Times Publishing House.

Lu, S. Y. \& Wu, Q. J. (2000): "Translation Teaching and Research in the 21st Century," Chinese Translators Journal 1, pp. 41-43.

Luo, X. M. (2002): "On the Teaching of Translation in China: Problems and Perspectives," Chinese Translators Journal 4, pp. 56-58.

MA, Z. Y. (1998): A Brief History of Translation in China, China Translation \& Publishing Corporation.

Meng, Z. \& Yu, Z. T. (2003): “Translation and English Teaching," Shanghai Journal of Translators for Science and Technology 1, pp. 43-45.

Mu, L. (1999): Translation Teaching in China, Shanghai: Shanghai Foreign Language Education Press.

Ren, X. P. (2004): “Advanced Translator Training in Ministry of Foreign Affairs," Chinese Translators Journal 1, pp. 61-62.

TAN, B. Q. (1997): Modern English Translation Skills, Shanghai: Shanghai Jiaotong University Press.

Tian, Y. (2002): "Modern Information Technology and Translation Teaching \& Training," Shanghai Journal of Translators for Science and Technology 3, pp. 30-33.

WAng, D. W. (1997): "Some Problems in Interpreting Teaching," Shanghai Journal of Translators for Science and Technology 4, pp. 17-20.

Wang, F. X. (1992): Chinese-English Interpretation Course, Beijing: Peking University Press.

Wang, L. D. (2000): “Innovations in Translation Training," Chinese Translators Journal 5, pp. 34-36. 
Wang, L. D. (2001): “Schema Theory in Translation," Chinese Translators Journal 2, pp. 19-25.

Wang L. D. (2003): “Translator Accreditation Tests and Translator Training," Chinese Translators Journal 6, pp. 51-54.

Wang, S. H. (2001): “On Translation Teaching for Undergraduate Students," Chinese Translators Journal,5, pp. 36-38.

WANG, X. X. (2004): “Emergency' Strategies for Interpreters," Chinese Science \& Technology Translators Journal 1, pp. 19-22.

Wu, B. et al. (1995): A Course in Oral Interpretation (revised edition), Beijing: Foreign Language Teaching and Research Press.

The State General Administration of Quality Supervision, Inspection and Quarantine of PRC (2003): Specification for Translation Service - Part 1: Translation, Beijing: China Standardization Press.

Xu, J. Z. (2002): An Introduction To Enterprise Translation, Beijing: China Translation \& Publishing Corporation.

Xu, J. Z. (2000): “Translation Variation,” Translatio 4, pp. 384-397.

Xu, L. N. (1997): "On Translation Teaching for Undergraduate Students," Shanghai Journal of Translators for Science and Technology 4, pp. 30-33.

Xu, Y. N. (2000): "Features in Diplomatic Interpretation of Translation and Diplomatic Interpreters' Qualities," Chinese Translators Journal 3, pp. 35-38.

Yan, L. L. (2000): "How Does Sci-Tech Translation Adapt to Information Times," Chinese Science \& Technology Translators Journal 1, p. 32.

YAng, L. (2001): "New Approaches of Translation Studies and Translation Teaching," Chinese Translators Journal 5, pp. 3-5.

YANG, L. (1993): A Course in English-Chinese \& Chinese-English Translation, Kaifeng: Henan University Press.

YANG, L. \& Zhang, B. R. (2003): “'Wisdom' and 'Techniques': In Translation Teaching Is Neglected by the Translation Circle in China," Chinese Science \& Technology Translators Journal 1, pp. 21-22, 20.

YANG, M. (2001): "Test for Certificate of English Interpreter and Its Training Course of Translation," Shanghai Journal of Translators for Science and Technology 3, pp. 32-35.

Zeng, L. S. (2002): "On the Formulaic Approach to the Teaching of Translation Theories and the Integration of Cross-disciplinary Theoretical Knowledge into the Practice of Translation," Chinese Translators Journal 1, pp. 35-39.

Zhang, B. J. (2003): “Teaching Interpretation in a Simulated Realistic Environment," Chinese Translators Journal 3, pp. 37-39.

Zhang, J. L. (2003): "A Comparative Study of Consecutive Interpreting and Simultaneous Interpreting," Shanghai Journal of Translators for Science and Technology, 1, pp. 33-36.

Zhang. L. (2000): "A Findings Report on College English Translation Teaching," Shanghai Journal of Translators for Science and Technology 3, pp. 46-49.

Zhang, L. L. (1996): Practical English-Chinese Translation Skills, Guangzhou: Guangdong Education Publishing House.

Zhang, M. F. (2001): English/Chinese Translation Textbooks in China (1949-1998), Shanghai: Shanghai Foreign Language Education Press.

Zhang, P. J. (1980): A Coursebook of English-Chinese Translation, Shanghai: Shanghai Foreign Language Education Press.

Zhong, W. H. (2001): "Interpreting Training: Models and Methodology," Chinese Translators Journal 2, pp. 30-33.

Zhong, W. H. (2001): “Simultaneous Interpreting: Principles and Training," Chinese Translators Journal 5, pp. 39-42.

Zhong, W. H. (2003): "Knowledge Requirements for Interpreters and Their Implication to Interpreting Course Designing," Chinese Translators Journal 4, pp. 63-65. 